Original Article

\title{
STABILITY INDICATING METHOD DEVELOPMENT AND VALIDATION FOR THE ESTIMATION OF PANOBINOSTAT LACTATEIN PHARMACEUTICAL DOSAGE FORMS BY UPLC
}

\author{
GORJA ASHOK ${ }^{1 *}$, SUMANTA MONDAL ${ }^{2}$ \\ 1Department of Pharmaceutical Analysis and QA, Faculty of Pharmacy, Gland Institute of Pharmaceutical Sciences, Kothapet, Medak \\ 502313, Telangana, India, '2Department of Pharmaceutical Chemistry, Faculty of Pharmacy, GITAM Institute of Pharmacy GITAM \\ University, Rushikonda, Visakhapatnam 500045, Andhra Pradesh, India \\ Email: ashokgorja8@gmail.com
}

Received: 02 Aug 2018 Revised and Accepted: 04 Oct 2018

\section{ABSTRACT}

Objective: The present study aimed to develop a stability indicating ultra-performance liquid chromatography (UPLC) method for the estimation of panobinostat lactate in pharmaceutical dosage form and validate the method in accordance with ICH guidelines.

Methods: The optimized conditions for the developed UPLC method are acquity UPLC hibar C18 $(100 \mathrm{~mm} \times 2.1 \mathrm{~mm}, 1.8 \mu)$ column maintained at $30^{\circ} \mathrm{C}$ with mobile phase consisting of $0.1 \%$ ortho phosphoric acid and acetonitrile in the ratio $50: 50 \% \mathrm{v} / \mathrm{v}$ on isocratic mode at flow rate $0.3 \mathrm{ml} / \mathrm{min}$. The sample was detected at $266 \mathrm{~nm}$.

Results: The retention time for panobinostat was found to be $1.6 \mathrm{~min}$. The developed method was validated for accuracy, precision, specificity, ruggedness, robustness and solution stability. The method obeyed Beer's law in the concentration range of $50 \mu \mathrm{g} / \mathrm{ml}$ and $300 \mu \mathrm{g} / \mathrm{ml}$ with correlation coefficient of 0.9998 . Forced degradation studies were conducted by exposing the drug solution to various stress conditions such as acidic, basic, peroxide, neutral, photolytic and thermal conditions. The net degradation was found to be within the limits, indicating that drug is stable in stressed conditions.

Conclusion: The developed method for the estimation ofpanobinostat can be utilized for the routine analysis of pharmaceutical dosage form.

Keywords: Panobinostat lactate, Stability indicating, Method development, Validation, UPLC

(c) 2018 The Authors. Published by Innovare Academic Sciences Pvt Ltd. This is an open access article under the CC BY license (http://creativecommons.org/licenses/by/4.0/] DOI: http://dx.doi.org/10.22159/ijpps.2018v10i11.28900

\section{INTRODUCTION}

Panobinostat [1-5] (fig. 1), chemically defined as 2-Hydroxypropanoic acid, compd. with 2-(E)-N-hydroxy-3-[4-[[[2-(2-methyl-1H-indol-3yl)ethyl]amino]methyl]phenyl]-2-propenamide (1:1). It is white to slightly yellowish or brownish powder, slightly soluble in water. It has pKa values of 5.45 and 10.01. It belongs to anticancer category which acts by inhibiting multiple histone deacetylase enzymes, a mechanism leading to apoptosis of malignant cells via multiple pathways. It is used for the treatment of multiple myeloma [6, 7].

The literature survey reveals that there was only one method developed and validated for the estimation of Panobinostat using ultra-high performance liquid chromatography-mass spectrometry [8]. As there is no method reported using UPLC, the present study aimed to develop and validate an UPLC stability indicating method for the estimation of panobinostat in pharmaceutical dosage form.

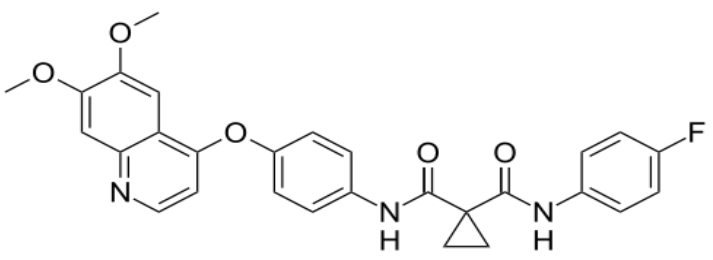

Fig. 1: Chemical structure of panobinostat

\section{MATERIALS AND METHODS}

Reagents and chemicals

Panobinostat working standard was procured from spectrum labs, Hyderabad as gift sample. The farydak tablets were purchased from local pharmacy. All the chemicals used were of AR grade purchased from Merck, Mumbai. All the solvents used were of HPLC grade purchased from Sigma-Aldrich, Mumbai.

Chromatographic conditions and instruments

The ACQUITY UPLC $[9,10]$ system equipped with binary solvent manager, sample manager, ultra violet (UV) detector and Hibar C18 $(100 \mathrm{~mm} \times 2.1 \mathrm{~mm}, 1.8 \mu)$ column was used for the determination of panobinostat. The optimized conditions included $0.1 \%$ ortho phosphoric acid (OPA) and acetonitrile $(50: 50 \% \mathrm{v} / \mathrm{v})$ as mobile phase run on an isocratic mode at flow rate $0.3 \mathrm{ml} / \mathrm{min}$. The column was maintained at $30^{\circ} \mathrm{C}$ and detection was done at $266 \mathrm{~nm}$. Other equipment used in the method was $\mathrm{pH}$ meter, ultrasonic bath sonicator and weighing balance.

\section{Preparation of diluent}

Mixture of water and acetonitrile in the ratio $50: 50 \% \mathrm{v} / \mathrm{v}$ was used as diluent.

Preparation of mobile phase

Mixture of $0.1 \%$ ortho phosphoric acid and acetonitrile in the ratio $50: 50 \% \mathrm{v} / \mathrm{v}$ was used as mobile phase

\section{Preparation of Standard and Sample solutions}

$200 \mathrm{mg}$ of panobinostat working standard was dissolved in $100 \mathrm{ml}$ of diluent. $1 \mathrm{ml}$ of the above stock solution was diluted to $10 \mathrm{ml}$ using diluent in order to get a concentration of $200 \mu \mathrm{g} / \mathrm{ml}$.

20 Tablets (Farydak) were weighed accurately and average weight was calculated. An amount equivalent to $200 \mathrm{mg}$ of drug was dissolved in $100 \mathrm{ml}$ of diluent. Filtered the solution and diluted $1 \mathrm{ml}$ of above solution to $10 \mathrm{ml}$ with diluent. 


\section{Method validation}

The developed method was validated in compliance with International Conference on Harmonization (ICH) guidelines [11, 12]

\section{Specificity}

The specificity of the method was determined by comparing the drug solution with the placebo solution and observed for the interference of placebo peak with drug peak.

\section{Accuracy}

Accuracy of the method was determined by \% recovery. The drug solution along with sample was prepared in three concentration levels $50 \%, 100 \%$ and $150 \%$. Then the $\%$ recovery was calculated.

\section{Precision}

Precision of the method was estimated by injecting the six solutions of standard into the UPLC system and \% relative standard deviation (RSD) was calculated.

\section{Linearity}

Linearity of the method was determined by preparing series of dilutions ranging from $50 \mu \mathrm{g} / \mathrm{ml}-300 \mu \mathrm{g} / \mathrm{ml}$ and injecting them into UPLC system.

\section{Ruggedness}

Ruggedness was determined by injecting the six solutions of standard into UPLC for different days. The \%RSD was calculated.

\section{Robustness}

Robustness of the method was determined by varying the optimized analytical conditions such as mobile phase composition by $\pm 5 \%$, flow rate by $\pm 0.1 \mathrm{ml} / \mathrm{min}$ and column oven temperature by $\pm 5^{\circ} \mathrm{C}$.

\section{Solution stability}

Solution stability was estimated by analyzing the standard drug solution after storage for 24 hours under laboratory conditions.

\section{Forced degradation studies}

Forced degradation studies [13] were carried out for drug by exposing the drug solution to the various stress conditions such as acidic $\left(2 \mathrm{~N}\right.$ hydrochloric acid for $30 \mathrm{~min}$ at $60^{\circ} \mathrm{C}$ ), basic $(2 \mathrm{~N}$ sodium hydroxide for $30 \mathrm{~min}$ at $\left.60^{\circ} \mathrm{C}\right)$, peroxide $(20 \%$ hydrogen peroxide for $30 \mathrm{~min}$ at $60{ }^{\circ} \mathrm{C}$ ), neutral (refluxing the drug in water for 6 hours at $\left.60^{\circ} \mathrm{C}\right)$, photolytic $\left(105^{\circ} \mathrm{C}\right.$ for $6 \mathrm{~h}$ ) and thermal (exposing the drug solution to UV Light by keeping the beaker in UV Chamber for 7 days or 200 Watt hours $/ \mathrm{m}^{2}$ in photo stability chamber) conditions.

\section{RESULTS}

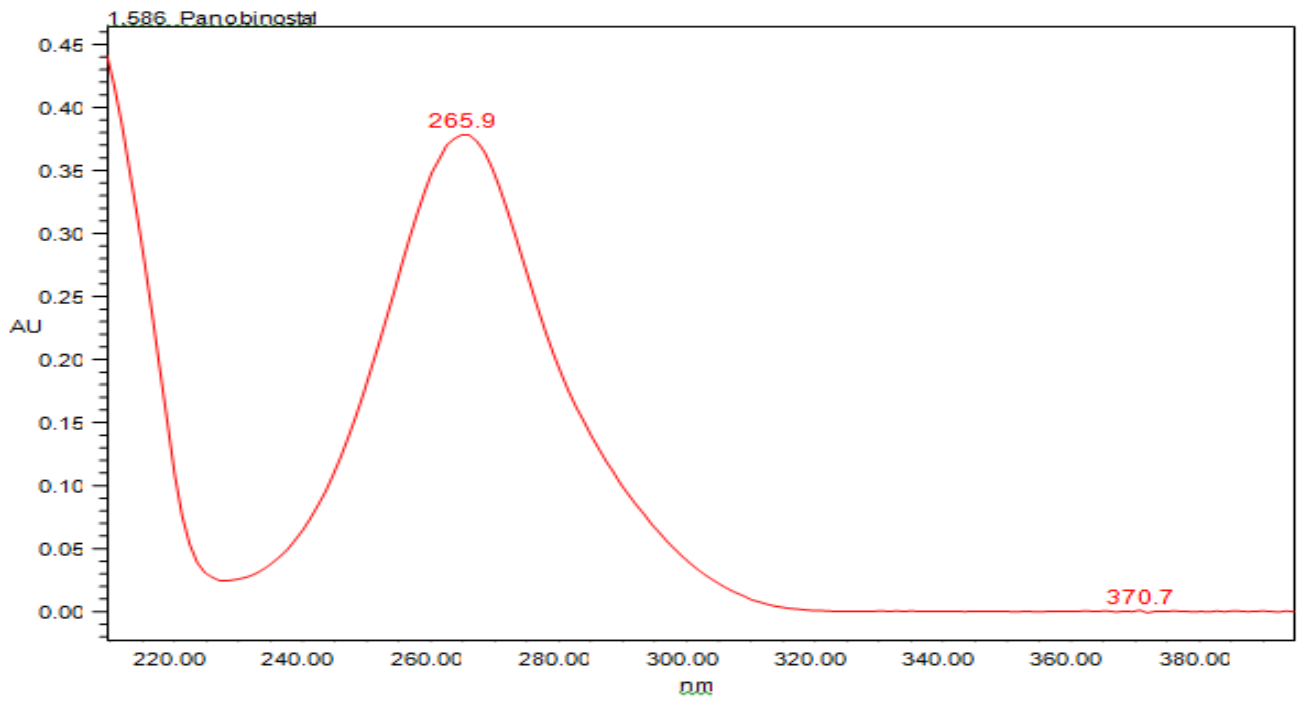

Fig. 2: UV Spectrum of panobinostat

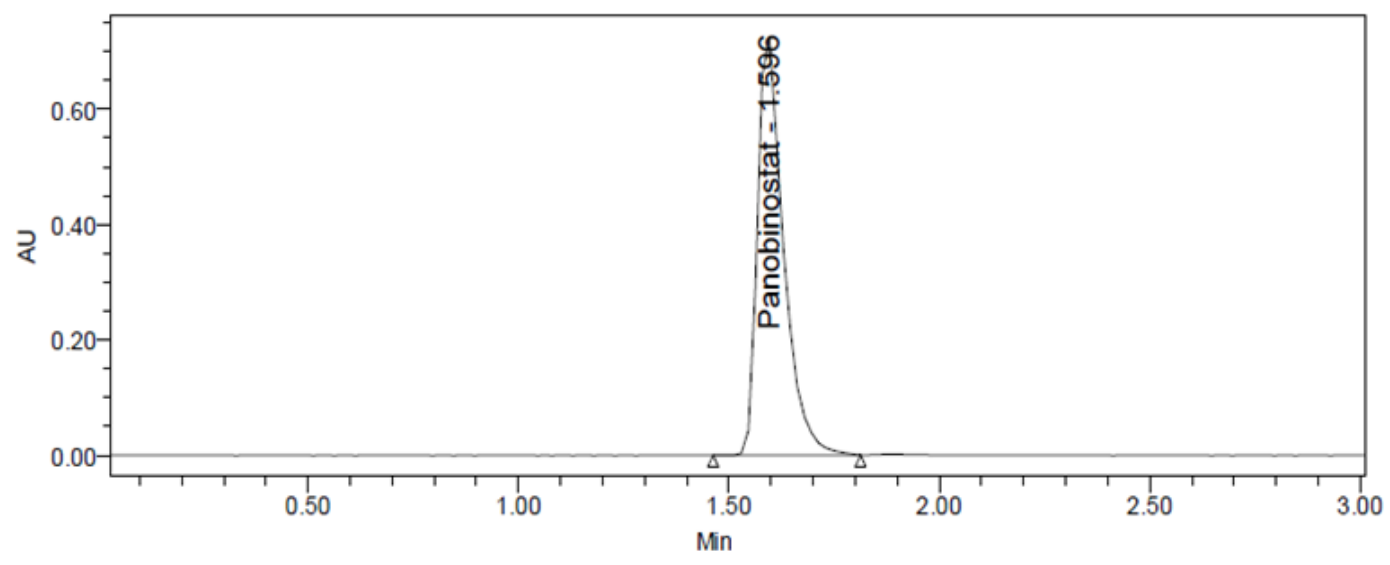

Fig. 3A: Standard chromatogram 


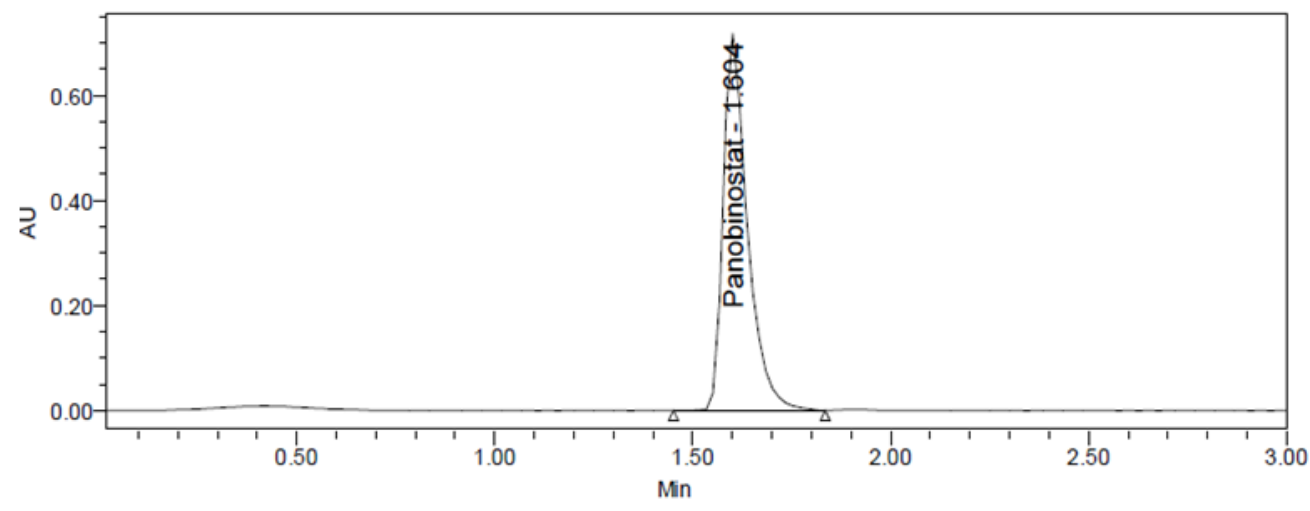

Fig. 3B: Sample chromatogram

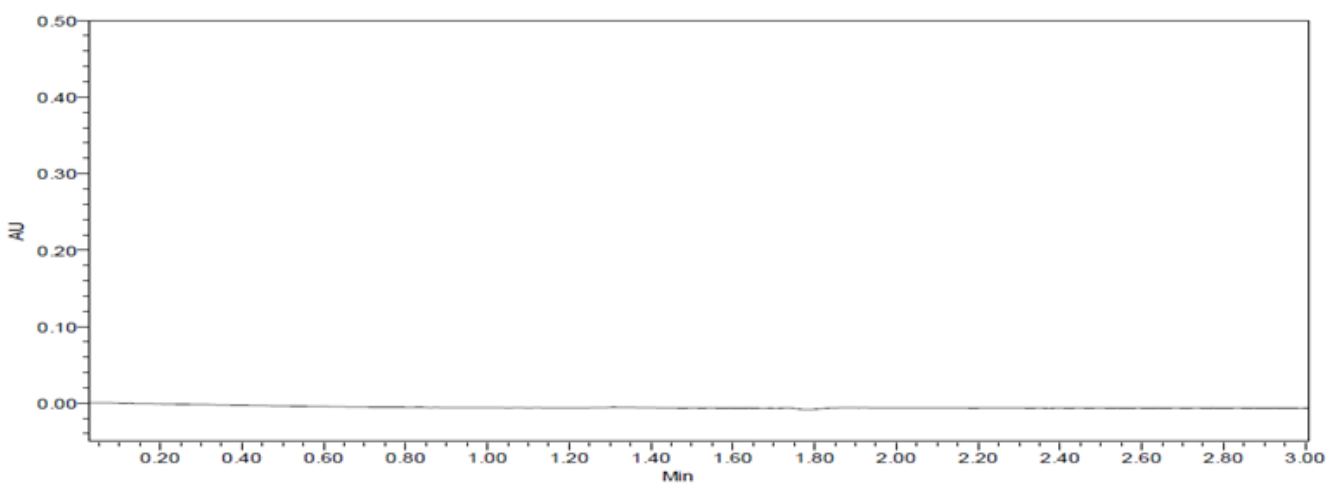

Fig. 3C: Blank chromatogram

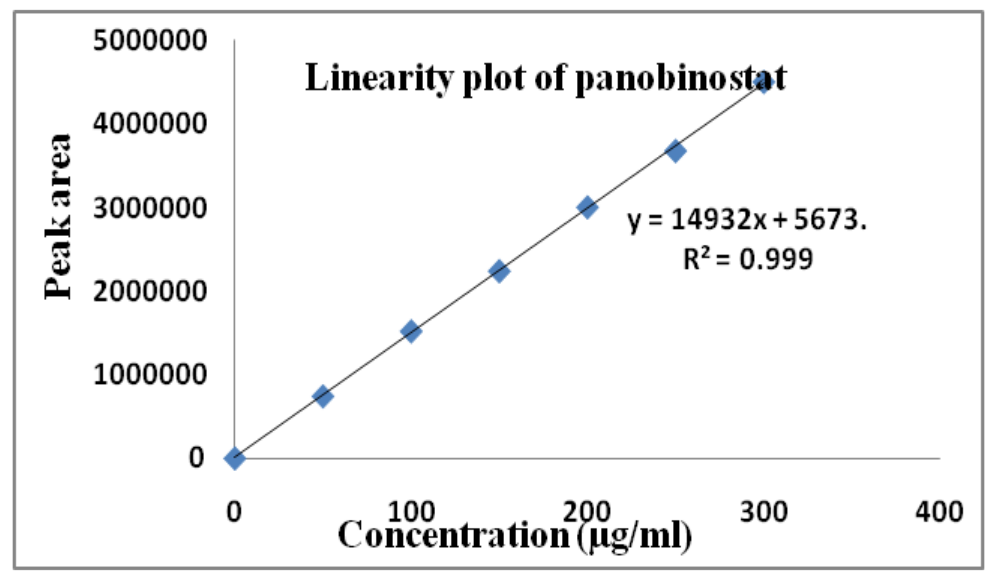

Fig. 4: Linearity plot of panobinostat

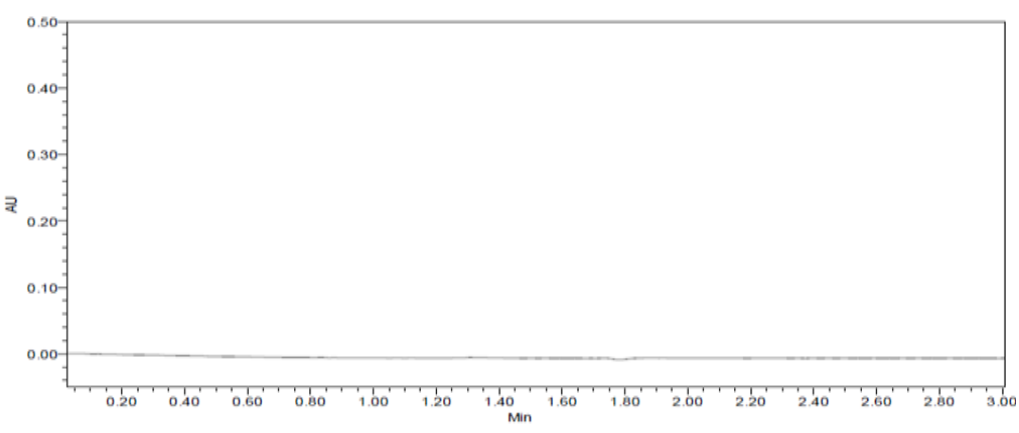

Fig. 5: Placebo chromatogram 
Table 1: System suitability and validation parameter results

\begin{tabular}{|c|c|c|}
\hline Parameter & Result(mean \pm SD) & \\
\hline Precision (\%RSD, n) & $0.98(100.13 \pm 0.98)$ & \\
\hline Accuracy (\% Recovery, n mean \pm SD) & $99.46 \% \pm 0.29-99.98 \% \pm 0.16$ & \\
\hline Specificity & Specific, No interference & \\
\hline Linearity range $(\mu \mathrm{g} / \mathrm{ml})$ & $50-300$ & \\
\hline Correlation coefficient, $\mathrm{r}$ & 0.9998 & \\
\hline Limit of Detection $(\mu \mathrm{g} / \mathrm{ml})$ & 0.19 & \\
\hline Limit of Quantitation $(\mu \mathrm{g} / \mathrm{ml})$ & 0.57 & \\
\hline \multirow[t]{2}{*}{ Ruggedness (\%RSD, n) } & Day 1 & Day 2 \\
\hline & 1.7 & 1.7 \\
\hline Robustness (\%RSD, n) & Less flow rate 1.4 & More flow rate 0.3 \\
\hline \multirow{2}{*}{ (Organic) } & Less mobile phase 1.3 & More mobile phase (Organic) 1.0 \\
\hline & Less column temperature 0.8 & More column temperature 1.1 \\
\hline Solution stability & Day $1(0 \mathrm{~h})$ & Day 2 (After 24 h) \\
\hline$(\% R S D, n)$ & 1.7 & 1.7 \\
\hline (\% Assay, n) & $100.13 \pm 0.98$ & $99.80 \pm 1.67$ \\
\hline USP Plate count & 3434 & \\
\hline USP Tailing factor & 1.46 & \\
\hline
\end{tabular}

n-number of samples, i.e., six samples for estimation

Table 2: Forced degradation studies result

\begin{tabular}{|c|c|c|c|}
\hline Stress condition & \% Assay & \% area of degradation peak & \% Degradation \\
\hline $2 \mathrm{~N} \mathrm{HCl}$ for $30 \min$ at $60^{\circ} \mathrm{C}$ & 95.90 & 3.65 & 4.10 \\
\hline $2 \mathrm{~N} \mathrm{NaOH}$ for $30 \mathrm{~min}$ at $60^{\circ} \mathrm{C}$ & 94.37 & - & 5.63 \\
\hline $20 \% \mathrm{H}_{2} \mathrm{O}_{2}$ for $30 \mathrm{~min}$ at $60^{\circ} \mathrm{C}$ & 97.10 & - & 2.90 \\
\hline Water for $6 \mathrm{~h}$ at $60^{\circ} \mathrm{C}$ & 99.32 & - & 0.68 \\
\hline UV light $200 \mathrm{wts} / \mathrm{h}$ or $7 \mathrm{~d}$ & 98.68 & - & 1.32 \\
\hline $105^{\circ} \mathrm{C}$ for $6 \mathrm{~h}$ & 98.04 & - & 1.96 \\
\hline
\end{tabular}

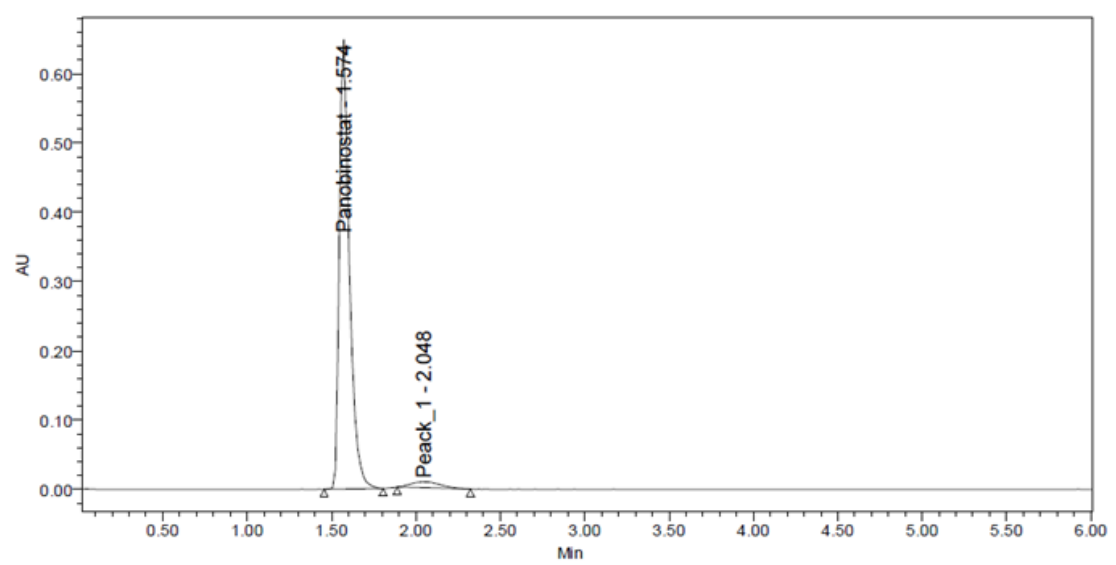

Fig. 6A: Acid degradation chromatogram

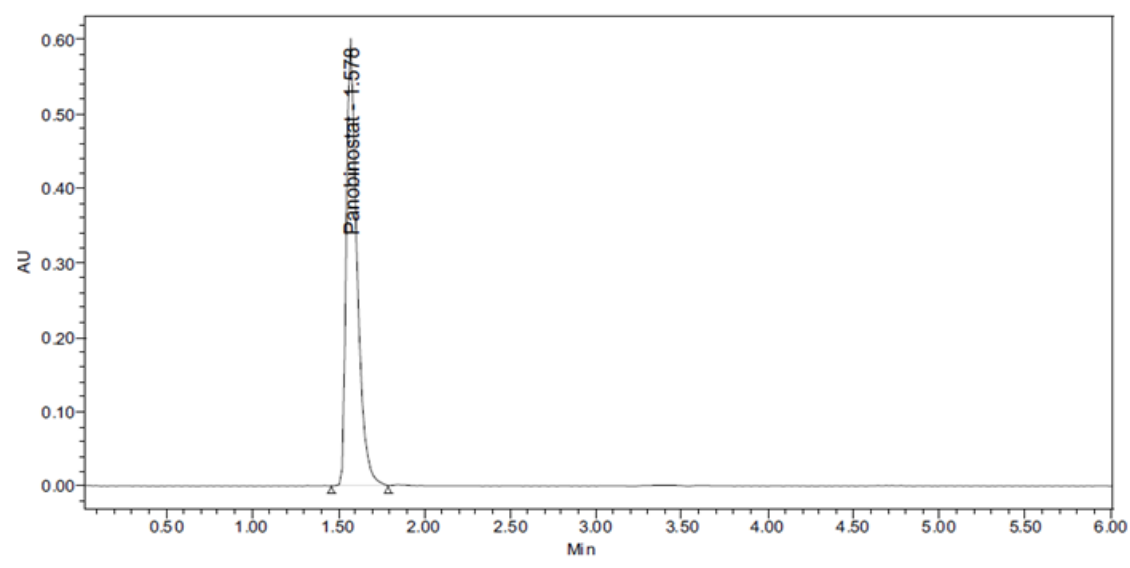

Fig. 6B: Base degradation chromatogram 


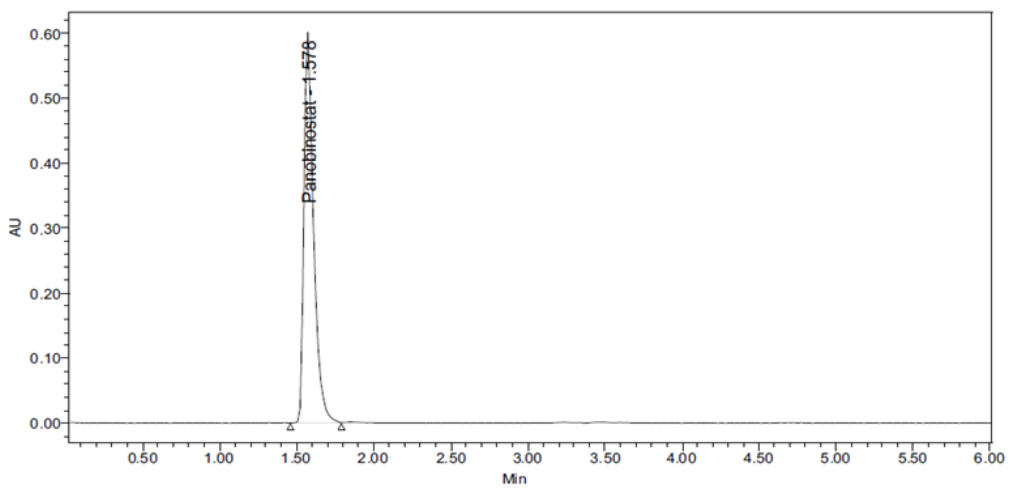

Fig. 6C: Peroxide degradation chromatogram

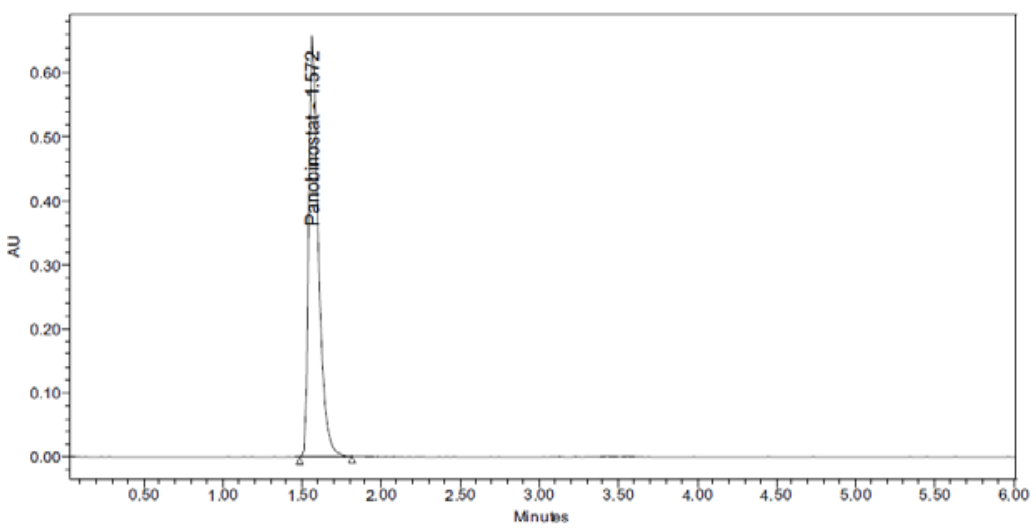

Fig. 6D: Water stress study chromatogram

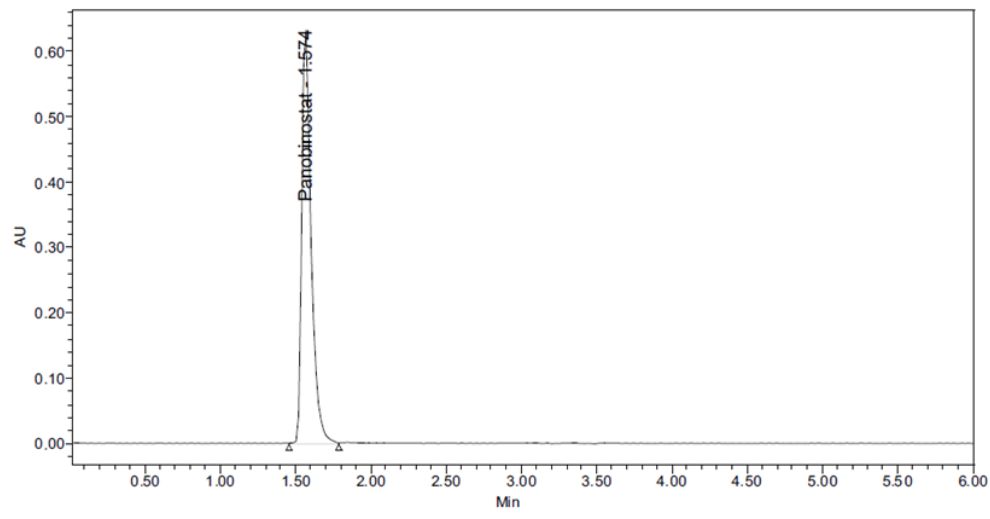

Fig. 6E: Photo stability degradation chromatogram

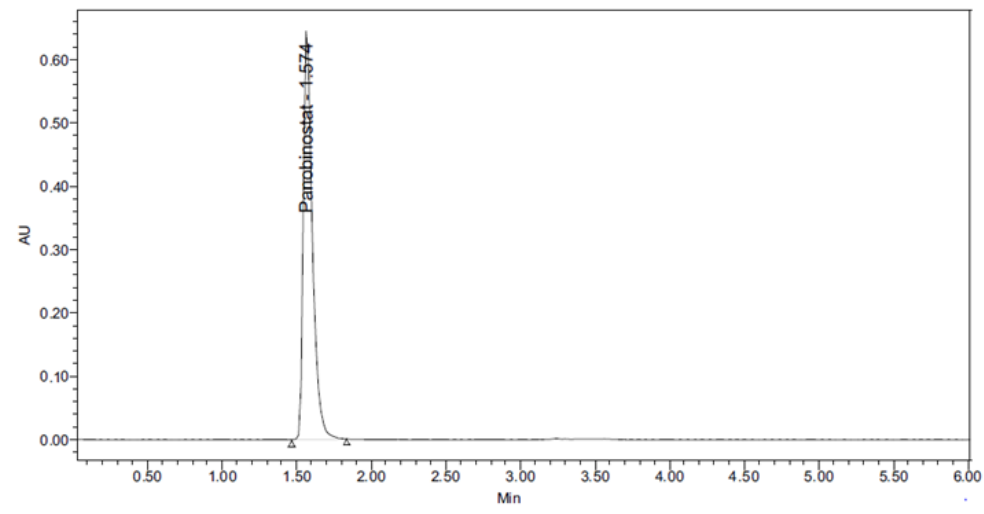

Fig. 6F: Dry heat study chromatogram 


\section{DISCUSSION}

For the development of method for the estimation of panobinostat in pharmaceutical dosage form initially many mobile phases and many columns were tried to elute the drug peak with less tailing factor and more plate count.

Acquity UPLC Hibar C18 $(100 \mathrm{~mm} \times 2.1 \mathrm{~mm}, 1.8 \mu)$ column and $0.1 \%$ OPA: Acetonitrile $(50: 50 \% \mathrm{v} / \mathrm{v})$ as mobile phase were selected based on peak parameters. The detection wavelength was found to be $266 \mathrm{~nm}$ as shown in fig. 2 of UV spectrum.

Prepared standard solution, sample solution and blank solution were injected into the UPLC system and system suitability parameters were noted as summarized in table 1 along with chromatograms as shown in fig. 3A, 3B and $3 \mathrm{C}$ respectively.

The developed method was found to obey Beer's law in the concentration range of $50 \mu \mathrm{g} / \mathrm{ml}-300 \mu \mathrm{g} / \mathrm{ml}$ with correlation coefficient of 0.9998. A linearity graph was plotted between concentration and peak area as shown in fig. 4 and results are summarized in table 1.

The method was found to be accurate as the \% recovery was $99.46 \%-99.98 \%$ and was within the limits. The \% RSD was found to be 0.98 , indicates that the method was precise. The method was found to be specific, as there is no interference of retention time of placebo peak with that of drug peak. The placebo chromatogram was shown in fig. 5 .

Forced degradation studies results indicate that the drug was found to be stable in various stress conditions as net degradation was found to be within the limits. The chromatograms were shown in fig. 6 and results were summarized in table 2 .

\section{CONCLUSION}

A specific, accurate, precise stability indicating method was developed for the estimation of panobinostat in pharmaceutical dosage form using UPLC. The method was validated by using various validation parameters and the method was found to be linear, precise, accurate, specific and robust. From the degradation studies conducted it is concluded that panobinostat were more stable at more concentrations of acid, base, peroxide, thermal, UV and water stress study conditions. The run time was 3 min which enables rapid quantitation of many samples in routine and quality control analysis of tablet formulations.

\section{AKNOWLEDGEMENT}

The authors are thankful to the Spectrum labs, Hyderabad for providing the panobinostat as the gift samples and also for providing required facilities to carry out this research work.

\section{AUTHORS CONTRIBUTIONS}

All authors contribute equally to this manuscript

\section{CONFLICTS OF INTERESTS}

The authors claim that they have no conflict of interest. It has not meant to publish elsewhere. And it has not meant simultaneously presented for publication elsewhere. All authors have decided to the submission to the journal.

\section{REFERENCES}

1. Prince HM, Bishton M. Panobinostat (LBH589): a novel pandeacetylase inhibitor with activity in T cell lymphoma. Hematology Meeting Reports. Parkville, Australia: Peter MacCallum Cancer Centre and University of Melbourne 2009;3:33-8

2. Revill P, Mealy N, Serradell N, Bolos J, Rosa E. Panobinostat. Drugs Future 2007;32:315

3. Rasmussen TA, Tolstrup M, Brinkmann CR, Olesen R, Erikstrup $\mathrm{C}$, Solomon $\mathrm{A}$, et al. Panobinostat, a histone deacetylase inhibitor, for latent-virus reactivation in HIV-infected patients on suppressive antiretroviral therapy: a phase $1 / 2$, single group, clinical trial. Lancet HIV 2014;1:e13.

4. Garbes L, Riessland M, Holker I, Heller R, Hauke J, Trankle Ch, et al LBH589 induces up to 10 fold SMN protein levels by several independent mechanisms and is effective even in cells from SMA patients non-responsive to valproate. Hum Mol Genet 2009;18:3645-58.

5. Tate CR, Rhodes LV, Segar HC, Driver JL, Pounder FN, Burow ME, et al. Targeting triple-negative breast cancer cells with the histone deacetylase inhibitor Panobinostat. Breast Cancer Res 2012;14:R79.

6. TA Rasmussen. Comparison of HDAC inhibitors in clinical development: effect on HIV production in latently infected cells and T-cell activation. Human Vaccines Immunother 2013;9:1-9.

7. Navin Patil, Balaji Ommurugan, Karthik S Udupa, Karthik Rao. Bortezomib induced subconjunctival hemorrhage. Asian J Pharm Clin Res 2017;10:10-1.

8. Estella-Hermoso de Mendoza A, Imbuluzqueta I, Campanero MA, Gonzalez D, Vilas-Zornoza A, Agirre X, et al. Development and validation of ultra-high performance liquid chromatography-mass spectrometry method for LBH589 in mouse plasma and tissues. J] Chromatogr B: Anal Technol Biomed Life Sci 2011;879:3490-6.

9. Madhavi S, Prameela Rani A. Simultaneous reverse phase ultraperformance liquid chromatography method development and validation for estimation of Grazoprevir and Elbasvir. Asian J Pharm Clin Res 2018;11:100.

10. Kishorkumar L Mule. Rapid analytical method for assay determination for prochlorperazine edisylate drug substances by Ultra performance liquid chromatography. Int J Curr Pharm Res 2017;9:118-22.

11. ICH: Q2 (R1), Validation of analytical procedures: text and methodology; 2005.

12. ICH: Q2B. Harmonized Tripartite Guideline, Validation of Analytical Procedure: Methodology, IFPMA, in: Proceedings of the International Conference on Harmonization, Geneva; 1996.

13. Ngwa G. Forced degradation studies as an integral part of HPLC stability indicating method development. Drug Delivery Technol 2010;10:56-9. 